\title{
The Decrease in Hospital Visits at Universitas Sebelas Maret Hospital Due to the Level of Stress and Fear of COVID 19
}

\author{
Nurhasan Agung Prabowo ${ }^{1,10, *}$ Hendrastutik Apriningsih ${ }^{2,11}$ Paramasari Dirgahayu ${ }^{3,12}$
}

Tonang Dwi Ardyanto ${ }^{4,13}$ Muchtar Hanafi ${ }^{5,14}$ Astri Tantri Indriani ${ }^{6,15}$ Frieska Dyanneza ${ }^{7,16}$ Niken Dyah Aryani Kuncorowati ${ }^{8,17}$ Laily Shofiyah ${ }^{9,18}$

1,2,3,4,5,6,7,8,9 Faculty of Medicine, Sebelas Maret University
10,11,12,13,14,15,16,17,18 Universitas Sebelas Maret Hospital
${ }^{*}$ Corresponding author. Email: bund4syab1l@gmail.com

\begin{abstract}
Background: In the current COVID-19 pandemic, the number of hospital visits was significantly decreased. There was a decrease in the number of outpatient visits from 9911 patients in January to 5586 patients in May 2020 in UNS hospital. This study aims to know the association the level of stress, hospital service quality, and fear of COVID 19 with hospital visits at UNS Hospital. Research methods: The study was conducted at UNS Hospital in July 2020 using the questionnaire method. Research tools with hospital service quality questionnaire, stress level questionnaire, fear for COVID-19 scale. The patient group was divided into two, the on-time outpatient group, which always met the schedule visit doctor, and the loss of follow-up outpatient, which was a late schedule to the hospital. Statistical test using t-test and Mann Whitney test, $\mathrm{p}<0,05$. Results: The COVID-19 fear score $(14.8+6.89)$ and the stress level $(13.95+6.1)$ were higher in the out of follow-up outpatients compared to on-time outpatients. While the hospital service quality scores were quite right in all study groups and were not significantly different in the two groups $($ mean $21.70+2.08)$. The results showed that the lost follow-up outpatients were associated with COVID-19 fear scores $(p=$ 0.001) and stress levels $(\mathrm{p}=0.001)$, and were not related to hospital quality service levels. Conclusion: The level of stress and fear of COVID 19 decrease hospital visits at UNS Hospital.
\end{abstract}

Keywords: level of stress, fear of COVID 19, quality of hospital services, hospital visits, UNS Hospital

\section{INTRODUCTION}

The COVID 19 pandemic is the most crucial health disaster globally, and the COVID-19 pandemic is the biggest challenge by humans since the 2nd World War. In December 2019, an infectious respiratory disease emerged in Wuhan, China, and was named by WHO (World Health Organization) as COVID- 19 (coronavirus disease 2019). A type of Coronavirus known as SARS Cov 2 ((severe acute respiratory syndrome coronavirus 2 ) is the cause of this pandemic.[1]

Covid-19 cases in Indonesia are increasing day by day. In the Indonesian Ministry of Health data on September 12, 2020, data on the accumulation of cases were 214746 people, while cases under treatment were 53638, cases recovered as many as 152458 people, and cases died were 8650 people. Data in Central Java states that the number of cases of Covid-19 in Central Java is 17460 cases or $8.1 \%$ of the national total, active cases still being treated are 5352 people, with a cure rate of 10969 people, and a death rate of 1139 people. The case in Central Java is number 3rd nationally.[2]
The COVID 19 pandemic has resulted in a decrease in the number of outpatients in the United States, a decrease in the number of outpatient visits aimed at reducing the risk of transmission of the Coronavirus from patient to patient or health workers, so there has been a decrease in the number of patient visits and an increase in technology in telemedicine.[3] Universitas Sebelas Maret (UNS) Hospital is a Type C hospital with approximately 150 beds in the Sukoharjo area. This hospital is a reference for COVID-19. Since the COVID 19 pandemic, the number of outpatients visits to the hospital has decreased, where in January, there were approximately 9911 outpatient visits decreased in May by 5886 patients. From initial interviews with several patients, it was found that the fear of covid-19 because the UNS hospital was a referral hospital, and the high level of stress in patients in the COVID-19 pandemic made the patient reluctant to go to the hospital. So we will analyze the cause of the decrease outpatient visits in UNS Hospital. This study aimed to analyze the reduction in the number of outpatients at the UNS hospital by examining the fear score of COVID 19, patient stress scores, and the quality of hospital services. 


\section{RESEARCH METHODS}

This research was conducted in June and July 2020 at the outpatient polyclinic of the UNS hospital. The study sample was 110 people who filled out a questionnaire and of the sample was divided into two groups, namely the ontime outpatient group who always routinely went to the hospital according to schedule and the loss of follow-up outpatient patients who did not routinely go to the hospital who were defined as patients who did not meet the scheduled check-in date to the hospital. This research has been cleared by the ethical committee of the Universitas Sebelas Maret Faculty of Medicine with ethical clearance number 059/UN27.06.6.1/ KEPK/EC/2020.

In determining the sample size in this study, researchers used the formula from Taro Yamane as follows:

$$
\mathbf{n}=\frac{N}{N d^{2}+1}
$$

$\mathrm{n}=$ Number of Samples $\mathrm{N}=$ Number of Population $\mathrm{d} 2=$ Precision specified

It is known that the total population is $\mathrm{N}=2025$ patients and the level of precision is set at $\mathrm{d} 2=10 \%$. The sample size is 100 , to prevent data loss plus $10 \%$ to 110 .

This research was conducted in June and July 2020 at the outpatient polyclinic of the UNS hospital. The study sample was 110 people who filled out a questionnaire, and of the sample was divided into two groups, patients who always routinely went to the hospital according to schedule and patients who did not routinely go to the hospital who were defined as patients who did not meet the scheduled check-in date to the hospital.

The questionnaires used are the perceived stress scale, the fear of COVID 19 questionnaires, and the hospital service quality questionnaire. The questionnaire was given with google form as an intermediary according to the adaptation of the new habits of the COVID-19 pandemic because giving paper questionnaires could cause the risk of COVID-19 transmission. The questionnaire has been validated in previous studies. The perceived stress scale [4] uses 10 question items, while the fear of COVID-195 uses 7 question items and the hospital service quality questionnaire [6] uses 7 question items. The questionnaire scale uses a Likert scale, "strongly disagree," "disagree," "neutral" "agree" and "strongly agree". An assessment of the sum of each questionnaire item's scores was carried out, a statistical test using an independent t-test or mann whyney test, and significant if $\mathrm{p}$ less than 0.05 .

\section{RESULTS}

The COVID-19 fear score $(14.8+6.89)$ and the stress level $(13.95+6.1)$ were higher in the loss of follow-up outpatients compared to on-time outpatients. While the hospital service quality scores were quite right in all study groups and were not significantly different in the two groups $(21.70+2.08)$. The results showed that the lost follow-up outpatients were associated with COVID-19 fear scores $(p=0.001)$ and stress levels $(p=0.001)$, and were not related to hospital quality service levels.

Table 1. Demographic Characteristics of Respondents Outpatients at the UNS Hospital

\begin{tabular}{lll}
\hline \multicolumn{1}{c}{ Characteristic } & Category & $\mathrm{n}$ \\
\hline Sex & Laki-laki & $19(16 \%)$ \\
& Perempuan & $91(84 \%)$ \\
Age & $26-35$ & $2(0,9 \%)$ \\
& $36-45$ & $10(8,5 \%)$ \\
level of education & $46-65$ & $98(90,6 \%)$ \\
& No school & $15(13,2 \%)$ \\
& Elementary & $64(59,4 \%)$ \\
& school & $27(24,5 \%)$ \\
& High School & $4(2,8 \%)$ \\
& University & \\
Job & Housewife & $76(69,8 \%)$ \\
& Wiraswasta & $15(12,6 \%)$ \\
& Entrepreneur & $13(11,3 \%)$ \\
& No Job & $3(2,8 \%)$ \\
& government & $3(2,8 \%)$ \\
& employees &
\end{tabular}

Table 2. The COVID-19 fear score, the perceived stress level score, and the hospital service quality score between on-time and loss of follow up outpatient.

\begin{tabular}{|c|c|c|c|c|}
\hline & $\begin{array}{l}\text { The on } \\
\text { time } \\
\text { outpatient } \\
\text { group }\end{array}$ & $\begin{array}{ll}\text { The Loss of } \\
\text { follow } \\
\text { outpatient } \\
\text { group }\end{array}$ & All & $\mathrm{p}$ \\
\hline The & $10,7 \pm$ & $16,7 \pm 5,55$ & 14.8 & 0,001 \\
\hline $\begin{array}{l}\text { COVID-19 } \\
\text { fear score }\end{array}$ & $3,55^{-}$ & & $\frac{ \pm}{6.89}$ & \\
\hline $\begin{array}{l}\text { The } \\
\text { perceived } \\
\text { stress level } \\
\text { score }\end{array}$ & $\begin{array}{c}10,2 \pm \\
3,45\end{array}$ & $15,9 \pm 6,39$ & $\begin{array}{r}13.95 \\
\pm 6.1\end{array}$ & 0,001 \\
\hline $\begin{array}{l}\text { The } \\
\text { hospital } \\
\text { service } \\
\text { quality } \\
\text { score }\end{array}$ & $\begin{array}{c}22,3 \pm \\
1,53\end{array}$ & $21,2 \pm 2,34$ & $\begin{array}{l}21.70 \\
+\frac{}{2.08}\end{array}$ & 0,171 \\
\hline
\end{tabular}




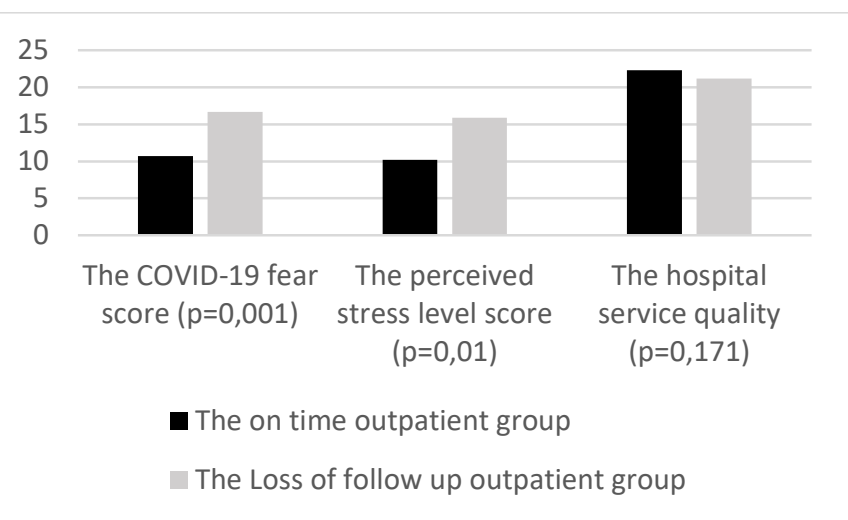

Fig.1. Bar chart The COVID-19 fear score, the perceived stress level score, and the hospital service quality score between on-time and loss of follow up outpatient.

The results showed that from outpatients at the UNS Hospital polyclinic, it was found that the fear of COVID 19 was lower in patients who were on time group $(10,7 \pm 3,55)$ than patients who were lost to follow up $(16,7 \pm 5,55)$. The stress level of patients on time group $(10,2 \pm 3,45)$ was also lower than that of patients who had lost the follow-up group $(15,9 \pm 6,39)$. While the quality of hospital services, according to patients, whether on-time group $(22,3+1,53)$ or loss of follow-up group $(21,2+2,34)$, all were excellent hospital services and data were not significantly different between the two patient groups.

\section{DISCUSSION}

Fear of COVID-19 Scale items are: I am most afraid of Corona, It makes me uncomfortable to think about Corona, My hands become clammy when I think about Corona, I am afraid of losing my life because of Corona, When I watch news and stories about Corona on social media, I become nervous or anxious, I cannot sleep because I am worrying about getting Corona, My heart races or palpitates when I think about getting Corona.[7] Several studies have shown that a poll conducted by several institutions that COVID-19 causes people to postpone hospital visits due to fear of COVID-19 [8].

A poll conducted on the Hospital-management.net showed that the pandemic is making people very reluctant to make in-person hospital visits and causing the cancellation of doctor appointments at the hospital. As many as $43 \%$ of respondents agreed that the pandemic made them reluctant to visit doctors in hospitals and cancel appointments, while $36 \%$ were reluctant to visit doctors but wanted to be in contact with telemedicine while $22 \%$ of respondents still visiting doctors at local hospitals even though there was a pandemic [8]. The same thing happened in UNS hospitals. Although there is no definite number of patients who postpone their check-up to the hospital, one indicator of the decline in the number of outpatients at UNS hospitals is one reason for fear of COVID-19. Especially after the UNS Hospital was designated as a COVID-19 referral hospital and this became the input for the management of the UNS Hospital to manage the COVID and non-COVID service areas so that patients would not become more afraid so that they would delay outpatient care.

The coronavirus pandemic in Indonesia has an unprecedented psychological impact on Indonesia people. A study took samples of the people who were spread across eight islands in Indonesia using snowball sampling. They responded to the DASS-42 questionnaire, totaling 644 respondents. The results of this study indicate that around $65.8 \%$ of respondents to health workers in Indonesia experience anxiety due to the COVID 19 outbreak, as many as $3.3 \%$ experience very severe anxiety, and $33.1 \%$ experience mild anxiety. Meanwhile, those who experienced stress due to the COVID 19 outbreak were $55 \%, 0.8 \%$ burdensome stress levels, and $34.5 \%$ mild stress.[9]

Perceived stress scale (PSS) questionnaire is designed to tap the degree to which respondents found their lives unpredictable, uncontrollable, and overloading [10]. PSS was developed by Cohen $\mathrm{S}$ et al.[10] to measure the degree to which situations in an individual's life are appraised as stressful. PSS has become one of the most widely used psychological instruments for measuring non-specific perceived stress.[11,12] PSS predicts both the objective biological markers of stress and the increased risk for disease among persons with higher perceived levels of stress.[13] In this study, it was found that moderate stress occurred in all groups, wherein the group with a regular schedule the stress was lower $(10,2+3,45)$, including mild stress, while in patients who irregularly visited the hospital, it was found that higher stress $(15,9+6,39)$, while the stress itself caused aggravation of the primary disease.

A new trend in international hospital services today is how to build patient-focused services and provide safer health services based on continuous quality improvement [14]. The current public demand is that hospitals must provide one-stop services, meaning that all health service needs related to patients must be served by the hospital quickly, accurately, with quality, and affordable, which can provide satisfaction in the results of treatment according to the disease which he suffered [15].

Quality services meet the needs of the community as customers. Excellent service is the primary key in service at the hospital. The prime service strategy is that every hospital must provide health services that include promotive, preventive, curative, and rehabilitative services through minimum service standards oriented to patient satisfaction [16]. The creation of comfort and satisfaction for patients who seek treatment at the hospital will increase visits, which will impact increasing the source of income for the hospital.[17] In this study, it was found that the quality of the UNS Hospital, according to the patient, is excellent, based on the score or analysis of the quality of hospital services, and this condition needs to be maintained for the future in order to maintain the quality of service to the community. 


\section{CONCLUSION}

The level of stress and fear of COVID 19 decrease hospital visits at UNS Hospital, although hospital services, according to patients, are excellent hospital services. This research will be used as input for the hospital management in implementing hospital strategies so that they can survive during the COVID-19 pandemic.

\section{AUTHORS' CONTRIBUTIONS}

Data gathering and idea owner of this study, Study design, Data gathering, Writing and submitting manuscript, Editing and approval of final draft, all events done by all the authors. All authors read and approved the final manuscript.

\section{ACKNOWLEDGMENTS}

The authors acknowledge the contribution of all research assistants involved in the collection of data. The authors express their profound gratitude to all participants in the study.

\section{REFERENCES}

[1] Chakraborty I, Maity P. COVID-19 outbreak: Migration, effects on society, global environment and prevention. Science of The Total Environment. 2020 Aug;728:138882.

[2] Kementerian Kesehatan. Dashboard Kasus COVID-19 di Indonesia [Internet]. Dashboard Kasus COVID-19 di Indonesia. 2020 [cited $2020 \mathrm{Sep} 13$ ]. Available from: https://www.kemkes.go.id/article/view/20031900002/ Dashboard-Data-Kasus-COVID-19-di-Indonesia.html

[3] Ateev Mehrotra, Michael Chernew, David Linetsky, Hilary Hatch, David Cutler, and Eric C. Schneider. The Impact of the COVID-19 Pandemic on Outpatient Visits: Changing Patterns of Care in the Newest COVID-19 Hot Spots [Internet]. 2020 [cited 2020 Sep 13]. Available from: https://www.commonwealthfund.org/publications/202 0/aug/impact-covid-19-pandemic-outpatient-visitschanging-patterns-care-newest

[4] Manita E, Mawarpury M, Khairani M, Sari K. Hubungan Stres dan Kesejahteraan (Well-being) dengan Moderasi Kebersyukuran. gamajop. 2019 Oct 30;5(2):178.

[5] Pang NTP, Kamu A, Hambali NLB, Mun HC, Kassim MA, Mohamed NH, et al. Correction to: Malay Version of the Fear of COVID-19 Scale: Validity and Reliability. Int $\mathbf{J}$ Ment Health Addiction [Internet]. 2020 Jul 25 [cited 2020 Sep 13]; Available from: http://link.springer.com/10.1007/s11469-020-00373-2

[6] Desi Verania Umbara. Analisis Kualitas Pelayanan Terhadap Tingkat Kepuasan Konsumen. Muhammadiyah University of Surakarta; 2017.

[7] Ahorsu DK, Lin C-Y, Imani V, Saffari M, Griffiths MD, Pakpour AH. The Fear of COVID-19 Scale: Development and Initial Validation. Int J Ment Health Addiction [Internet]. 2020 Mar 27 [cited 2020 Sep 13]; Available from:
http://link.springer.com/10.1007/s11469-020-00270-8

[8] COVID-19 fears affect appointments for routine doctor visits: Poll [Internet]. 2020 Jul 25 [cited 2020 Sep 13]. Available from: https://www.hospitalmanagement.net/news/covid-19impact-on-routine-appointments-to-hospitals-doctors/
[9] Dede Nasrullah, Natsir M, Twistiandayani R, Siswanto, Rohayani L, dkk. Dampak Psikologis Tenaga Kesehatan dalam Upaya Menghadapi Pandemi Corona Virus (Covid-19) di Indonesia [internet]. 2020 Jul 25 [cited 2020 Sep 13]. Available from : http://sinta.ristekbrin.go.id/covid/penelitian/detail/245.

[10] Cohen S, Kamarck T, Mermelstein R. A global measure of perceived stress. Journal of Health and Social Behavior. 1983;24:385-96.

[11]Dong Y, Stupnisky RH, Berry JC. Multiple causal attributions: An investigation of college students learning a foreign language. European Journal of Psychology of Education. 2013;28(4):1587-602

[12] Kramer JR, Ledolter J, Manos GN, Bayless ML. Stress and metabolic control in diabetes mellitus: Methodological issues and an illustrative analysis. Annals of Behavioral Medicine. 2000;22(1):17-28

[13] Sinha P, Raju V, Babu J S, Chandolu S, Karan A, Nayyar AS. Assessment of Stress Levels in Patients Visiting for Dental Treatment. BEMS Reports. 2019 Mar 15;4(2):42-6.

[14] Supartiningsih, S. Kualitas Pelayanan dan Kepuasan Pasien Rumah Sakit : Kasus Pada Pasien Rawat Jalan di Rumah Sakit Sarila Husada Sragen. Jurnal Medicoeticolegal dan Manajemen Rumah Sakit, 6 (1): 9-15. 2017.

[15] Yulyuswarni, Y.Mutu Pelayanan Farmasi Untuk Kepuasan Pasien Rawat Jalan Di Instalasi Farmasi Rumah Sakit Swasta, Jurnal Keperawatan, Vol. X, No. 1, hal. 110-115. 2014.

[16] Utami, A.T., H. Ismanto dan Y. Lestari. Pengaruh Kualitas Pelayanan terhadap Kepuasan Pasien (Studi kasus pasien Rawat Jalan di UGD RS Bhayangkara Pusat Pendidikan Brigade Mobile Watukosek, Jurnal JKMP Vol. 1, No. 1. hal. 83-96. 2013.

[17] Fitriani, S. dan R. Trisnawati. Pengaruh Kualitas Pelayanan terhadap Loyalitas melalui Kepuasan Pasien Pengguna BPJS di Rawat Inap RSUD Dr. Moewardi, Jurnal Ekonomi Manajemen Sumber Daya Vol. 17, No. $1: 46-53.2015$. 